\title{
Phytochemical Screening, Acute Toxicity and Anti- Rabies Activities of Extracts of Selected Ethiopian Traditional Medicinal Plants
}

Yeweynshet Tesera ( $\nabla$ teswoy.200@gmail.com )

Ethiopian Public Health Institute

Asnake Desalegn

Addis Ababa University

Ashenif Tadele

Ethiopian Public Health Institute

Abebe Mengesha

Ethiopian Public Health Institute

Birhanu Hurisa

Ethiopian Public Health Institute

Jemal Mohammed

Ethiopian Public Health Institute

Demise Mulugeta

Ethiopian Public Health Institute

Sintayehu Ashenafi

Ethiopian Public Health Institute

Anberbir Alemu

Ethiopian Public Health Institute

Sileshi Degu

Ethiopian Public Health Institute

Ayele Bizuneh

Ethiopian Public Health Institute

\section{Research Article}

Keywords: Anti-rabies, Cytotoxicity, Pathogenicity, Phytochemicals, Traditional medicinal plants

Posted Date: May 20th, 2021

DOl: https://doi.org/10.21203/rs.3.rs-512523/v1 
License: (c) (i) This work is licensed under a Creative Commons Attribution 4.0 International License. Read Full License 
Phytochemical Screening, Acute Toxicity and Anti-Rabies Activities of Extracts of Selected Ethiopian Traditional Medicinal Plants

Yeweynshet Tesera ${ }^{1,2 *}$, Asnake Desalegn ${ }^{2}$, Ashenif Tadele ${ }^{1}$, Abebe Mengesha ${ }^{1}$, Birhanu Hurisa $^{1}$,

Jemal Mohammed ${ }^{1}$, Demise Mulugeta ${ }^{1}$, Sintayehu Ashenafi ${ }^{1}$, Anberbir Alemu ${ }^{1}$, Sileshi Degu1 and Ayele Bizuneh1

1 Ethiopian Public Health Institute, Addis Ababa, Ethiopia

2 Addis Ababa University, Department of Microbial, cellular and molecular biology, Addis Ababa, Ethiopia

*Corresponding Author: teswoy.200@gmail.com

ORCID ID: https://orcid.org/0000-0002-4177-1659 


\begin{abstract}
Background: Rabies, endemic in most African and Asian countries, is a viral zoonosis that causes an estimated 59,000 human deaths a year, despite the existence of safe and effective vaccines. In most developing countries people believe to cure rabies with different traditional and religious treatment rather than seeking effective post exposure prophylaxis.
\end{abstract}

Purpose: To investigate the phytochemical constituents, acute toxicity and antirabies activity of crude extracts of the leaves of Justicia schimperiana and Ricinus communis and the stem bark of Croton macrostachyus.

Methods: To test the presence of various phytochemicals, standard procedures were used. For the determination of acute toxicity and in vivo antirabies activities, Organization for Economic Corporation and Development (OECD) Guideline No.423 was used. Different concentrations of extracts $(0.4,0.8,1.6,3.2,6.4$ and $12.8 \mathrm{mg} / \mathrm{ml})$ were tested for their cytotoxic effect on Vero cells through 3-(4, 5-Dimethylthiazol-2-yl)-2, 5Diphenyltetrazolium Bromide (MTT) assay. The in vitro antirabies assay was carried out based on the minimal cytotoxic concentration of extracts.

Results: The phytochemical screening result has revealed the presence of alkaloids, flavonoids, phenols, steroids, tannins and terpenoids in all plant extracts screened but lack saponins. All the extracts were slightly toxic in Swiss albino mice model but non cytotoxic in Vero cell lines. The antirabies assay result showed that all plant extracts had a moderate to good antirabies potential. The methanol extracts exhibited higher antirabies activity compared to the other extracts under investigation.

Conclusion: The present study concluded that the studied plants have possessed different phytochemicals that helps in their antirabies potential. Utilization of these pharmacological properties involves further investigation of these active ingredients by implementation techniques of extraction, purification, separation, crystallization and identification.

Keywords/phrases: Anti-rabies, Cytotoxicity, Pathogenicity, Phytochemicals, Traditional medicinal plants 


\section{Introduction}

Rabies neglected viral zoonosis, is still a major public health problem all over the world which causes more than 50, 000 human deaths annually primarily in developing countries of Asia and Africa (Zulu et al., 2009). It is caused by a neurotropic, negative sense, non-segmented, singlestranded RNA virus that belongs to the Lyssavirus genus of the Rhabdoviridae family and Mononegavirale order, which causes physiological disorders by infecting the neurons at the central nervous system (Vural et al. 2016). All mammals are susceptible to rabies, but only a limited number of species also act as reservoir hosts (Balcha and Abdela 2016). The disease is mainly associated with dog bites in Europe, Asia, and Africa and with bats in the Americas (Hemachudha et al. 2013). In developing countries, the majority of confirmed and reported cases and over $90 \%$ of human exposures are from domestic dogs (Kaare et al. 2009). Rabies associated with bat RABV variants has atypical features, like focal brainstem signs, myoclonus, hemichorea, and signs and symptoms of Horner's syndrome (Hemachudha et al. 2013). It is generally transmitted through the bite of an infected mammal, but non-bite exposures also may occur under unusual circumstances. Exposure may occur by direct contact of saliva, nervous or other infected tissues from a rabid animal with mucous membranes, or from scratches. The disease is almost always fatal, once symptoms appear (Kuzmin and Rupprecht 2008).

Though rabies is prevalent throughout the world, many countries and islands like Australia and Antarctica, have got rabies-free status due to strict quarantine or by virtue of their water locked geographical location (Singh et al. 2017). Globally, it is estimated that approximately 50,000 to 100,000 people die from rabies each year, although the true number is probably much higher than what's being reported (Leung et al. 2007). In the United States, multiple RABV variants circulate in wild mammalian reservoir populations including raccoons, skunks, foxes, and bats. In the developing world like Ethiopia, it is recognized that the number of deaths due to rabies officially reported greatly underestimates the true incidence of disease (Knobel et al. 2005). Post exposure prophylaxis (PEP) consisting of rabies immune globulin and rabies vaccine is successful in preventing the disease if prompt intervention is initiated (Blanton et al. 2010).

Death is almost always inevitable in unimmunized patients; only supportive measures are recommended after the onset of neurological signs and symptoms (Crowcroft and Thampi 2016). However, the disease is $100 \%$ preventable by either pre-exposure prophylaxis (PrEP) or post- 
exposure prophylaxis (PEP) which together effectively prevent approximately 372,000 deaths yearly. Specifically, prompt administration of vaccines in conjunction with rabiesimmunoglobulins and proper wound management after exposure prevent rabies even after highrisk exposure (Nie et al. 2017). In Africa and Asia, almost 8 million people a year receive costly post-exposure prophylaxis (PEP) following bite injuries from rabid animals (Knobel et al. 2005) Although, a vaccine preventable disease, the annual number of human deaths caused by rabies is estimated to be more than 50, 000 per year, mostly in Africa and Asia (Okonko et al. 2010). The endemicity of rabies in developing countries like Ethiopia could be attributed to lack of risk communication, Poor surveillance of rabies-related viruses and poor diagnostic capability, low vaccine coverage and failure to immunize domestic dogs, which transmit rabies to humans.

Older nerve tissue vaccine is still being manufactured and utilized for the majority of exposed patients in Ethiopia, even though this vaccine has been discouraged by the WHO as they may induce severe adverse reactions and are less effective than CCEEVs, (Birhanu et al. 2013). The continuing burden of the disease in Ethiopia poses requirements for further development of affordable protective biologicals and treatment regimens for rabies. Many traditional medicinal plants have been reported to have strong antiviral activity and some of them have already been used to treat animals and people who suffer from viral infections. Phytolacca dodecandra, Justicia schimperiana, Ricinus communis, Brucea antidysenterica, Croton macrostachyus and Cucumis ficifolius were the most cited medicinal plant species utilized for the management of rabies in Ethiopia (Asfaw et al. 2017). Therefore, evaluations of the antirabies activity of such medicinal plant extracts are a necessary and highly desirable task. The present study had the objectives of assessing the phytochemical constituents, acute toxicity and antirabies potential of extracts from the leaves of Justicia schimperiana and Ricinus communis as well as the stem bark of Croton macrostachyus.

\section{Materials and Methods}

Study setting and design: The study was carried out at Ethiopian Public Health Institute (EPHI), Cell culture based antirabies vaccine production laboratory and Traditional and Modern Medicine laboratory from January 2019 to August 2019 with quantitative and descriptive methods.

Study population: Nine extracts from three plant species were evaluated on Swiss albino mice and Vero cell lines. 
Plant material collection and identification: The leaves of Justicia schimperiana and Ricinus communis and stem bark of Croton macrostachyus were collected from Menagesha District and identified at the National Herbarium, Department of Plant Biology and Biodiversity management, Addis Ababa University.

Processing and extract preparation: each plant part were properly washed and separated from foreign material, dried, chopped, crushed and powdered with electrical grinder (Hussain et al. 2011). The powdered plant samples were then extracted successively with solvents in the increasing order of their polarity using maceration techniques (Jemal et al. 2014).

Phytochemical screening: Qualitative screening for phytochemicals was carried out following standard procedures (Banu and Cathrine 2015; Khalid et al. 2018; Sasidharan et al. 2011; Wadood et al. 2013; Zohra et al. 2012;). The ethanol, methanol and water extracts of stem bark of Croton macrostachyus and the leaves of Justicia schimperiana and Ricinus communis were tested for the presence of alkaloids, flavonoids, phenol, steroids, saponins, tannins, terpenoids. The qualitative results are expressed as $(+)$ for the presence and $(-)$ for the absence of phytochemicals.

\section{Cell culture and virus}

Vero cells obtained from Vaccine and Diagnostics production directorate, EPHI were cultured using the T-75 culture flasks following the procedure described in (Ammerman et al. 2008). Briefly, Vero cells kept in liquid nitrogen were recovered from frozen stock in a $37^{\circ} \mathrm{C}$ water bath. The cell suspension was transferred from the cryovial into a $15 \mathrm{ml}$ conical tube containing $10 \mathrm{ml}$ of DMEM supplemented with FBS. The cells were pelleted by centrifugation at $200 \times \mathrm{g}$ for 5 minutes at room temperature and the supernatant was removed and discarded. The cells were resuspended in 5-10 ml DMEM supplemented with $10 \% \mathrm{FBS}$ and transferred to tissue culture flask with vented cap. Flasks were incubated in $37^{\circ} \mathrm{C}$ incubator with $5 \% \mathrm{CO}_{2}$ for $2-3$ days until a monolayer was obtained. The growth medium from confluent monolayer of Vero cells was removed and cells were washed with $10 \mathrm{ml}$ 1X DPBS. Five $\mathrm{ml}$ of $1 \mathrm{X}$ trypsin-EDTA was added and the cells were incubated at $37^{\circ} \mathrm{C}$ for 2-3 minutes, until cells start to streak as they detached from the flask. To inactivate the trypsin-EDTA, $5 \mathrm{ml}$ DMEM with 10\% FBS were added and cells were washed down in media. The cell suspension was removed from flask and transferred to a sterile $15 \mathrm{ml}$ conical tube and centrifuged at $200 \times \mathrm{g}$ for 5 minutes at room temperature. The cells were resuspended in $10 \mathrm{ml}$ DMEM with 10\% FBS after supernatant was removed and discarded. The desired dilution 
of cell culture cells in a total of $15 \mathrm{ml}$ DMEM with $10 \% \mathrm{FBS}$ was prepared and added to $75 \mathrm{~cm}^{2}$ cell culture flasks with vented caps. Flasks were incubated in $37^{\circ} \mathrm{C}$ incubator with $5 \% \mathrm{CO} 2$ until a monolayer was obtained. Finally, cells were collected within a volume of 20-30 ml in cell culture medium with $10 \%$ heat-inactivated FBS. Cells were maintained at $37{ }^{\circ} \mathrm{C}$ under a humidified $5 \%$ $\mathrm{CO}_{2}$ atmosphere for bioassay.

The virus (PV) was propagated in Vero cells as previously described by (Webster and Clow 1937) and titer of infectious virus was obtained by the limit-dilution method and expressed as $50 \%$ tissue culture infections dose per ml (TCID50/ml). Briefly, serial 10-fold dilutions (10-1 to 10-7) of virus in serum-free MEM were added into the confluent monolayer in 96-well tissue culture plate and were incubated for $72 \mathrm{~h}$ at $37^{\circ} \mathrm{C}$. After incubation, the medium was decanted and the cells were fixed by adding cold acetone $\left(50 \mu \mathrm{l}\right.$ per well) and kept at $4^{\circ} \mathrm{C}$ for 30 minutes. After discarding the acetone, cells were stained by direct polyclonal florescent-labeled antibody for 30 minutes and washed three times with 0.01 M phosphate buffer saline (PBS), air dried, and visualized under an inverted fluorescence microscope. The titer was calculated by using Spearman-Karber method and expressed as TCID50. The virus titration was also performed in mice through intracerebral inoculation using serial ten-fold dilutions at a volume of $0.03 \mathrm{ml}$. Six mice were inoculated per virus dilution, and the end point was death. The statistical method of Spearman-Karber was used and the mortality at each dilution was calculated to determine the $50 \%$ end point titer (Ramakrishnan 2016).

\section{In vivo acute toxicity test:}

The extracts from the leaves of Justicia schimperiana and Ricinus communis and stem bark of Croton macrostachyus plants were assessed for their toxicity in female Swiss albino mice aged 34 weeks and with weight of 15-25g according to the standard guideline of Organization for Economic Cooperation and Development (OECD). A total of 276 Swiss albino mice were used and randomly divided into control and treatment groups; six mice per cage. The mice in the treatment groups received $0.5 \mathrm{ml}$ of the ethanol, methanol and water extracts of each plant respectively, at doses of 1000, 2000, 3000, 4000 and $5000 \mathrm{mg} / \mathrm{kg}$. And the mice in the control group received $0.5 \mathrm{ml}$ of respective vehicle of each extract (4\% Polysorbate-80) (OECD 2001). The mice were observed individually after dosing at least once during the first 30 minutes, and daily thereafter, for a total of 14 days (Asefa et al. 2010). For determination of LD50 of extracts, 
an exploratory assay with each tested mouse strain was performed in order to exactly determine the dose range to be used with accuracy. All observations were systematically recorded, with individual records being maintained for each mouse and at the end of the test surviving animals were humanely killed by cervical dislocation (OECD 2001).

\section{In vitro acute toxicity test:}

Evaluation of the cytotoxicity of ethanol, methanol and aqueous extracts towards the Vero cells was performed using MTT [3-(4, 5-dimethylthiazol-2-yl) -2, 5-diphenyl tetrazolium bromide] assay. Briefly, Vero cells were seeded in a 96-well flat-bottom microtiter plate at a density of $2 \times$ 105 cells $/ \mathrm{ml}$ and allowed to adhere for $24 \mathrm{~h}$ at $37^{\circ} \mathrm{C}$ in a $\mathrm{CO} 2$ incubator. After incubation, culture medium was replaced with a fresh medium and different concentrations $(0.4,0.8,1.6,3.2,6.4$ and $12.8 \mathrm{mg} / \mathrm{ml}$ ) of extracts were serially diluted in DMEM and added to each culture wells in triplicate. To the control cells only $100 \mu \mathrm{l}$ of the culture medium was added. The plates were incubated for 3 days at $37^{\circ} \mathrm{C}$ with $5 \% \mathrm{CO} 2$. Subsequently, the medium was removed and the cells washed by phosphate buffer saline (PBS) followed by the addition of $100 \mu \mathrm{l}$ of DMEM and $50 \mu 1$ of MTT working solution ( $5 \mathrm{mg} / \mathrm{ml}$ in phosphate buffer solution) to each well. The plates were then incubated for 3h. After incubation, MTT was aspirated, and the formed formazan crystals were solubilized by adding 50 $\mu \mathrm{l}$ of DMSO per well, followed by gentle shaking for $15 \mathrm{~min}$ (Fayyad et al. 2014). In this regard, 3-(4, 5-dimethylthiazol-2-yl)-2, 5-diphenyltetrazolium bromide (MTT) assay uses a water-soluble yellow tetrazolium salt (MTT), which is reduced to an insoluble purple formazan by viable cells. The absorbance of dissolved formazan, quantified spectrophotometrically, correlates with the number of intact viable cells. Finally, the intensity of the dissolved formazan crystals (purple color) was quantified using the ELISA plate reader at 490 $\mathrm{nm}$. Percentage of viable cells was obtained by dividing the mean absorbance at $490 \mathrm{~nm}$ of treated cells (for each concentration of extract) to the mean absorbance of its control cells (Soltanian et al. 2017).

\section{In vivo antirabies assay:}

The in vivo antirabies activities of plant extracts at the dose of $3000 \mathrm{mg} / \mathrm{kg}$ were compared with negative control based on the difference in mean survival time of group of mice challenged with rabies virus (PV). As described by (Asefa et al. 2010) after virus inoculation, the mice were allowed to stay in their respective cages for about 1 hour so as to make them calm. Then, the 
extracts diluted with $4 \%$ Polysorbate- 80 solvent were orally administered to the mice in the treatment groups by using an intra-gastric needle based on the animal's body weight in $1 \mathrm{ml}$ vehicle via gauge. Volume administered was calculated based on individual mouse body weight and 0.5 $\mathrm{ml}$ was the maximum volume administered. Extracts were administered via the oral route using gavage and all the groups of mice were observed for mortality up to 28 days.

\section{Determination of mean survival time}

Anti-rabies activities of the selected medicinal plant extracts were evaluated on mice survival period compared to negative control group. Mortality rates as a result of rabies virus challenge were determined by clinical signs and direct fluorescent antibody test (Petros et al. 2014). The mice were monitored daily for the sign of paralysis and mortality for about 28 days after inoculation of the virus. Death was recorded for each mouse in the treatment and control groups throughout the follow up period on the mouse history cards. The number of days each mouse survived was recorded for the mice in each group and mean survival time were calculated using the formula (Nafiu et al. 2013).

$\mathrm{MST}=\underline{\text { Sum of days of survival of mice/group }}$

total number of mice in the group

Confirmatory diagnosis of rabies through direct Fluorescent antibody test (FAT) was conducted by opening of the skulls and collection of the brain of mice was done according to the procedure specified by (Dean and Abelseth 1973). Brain impressions were made upon microscope slides, which were fixed by acetone and incubated with fluorescein isothiocyanate (FITC)-labeled antibodies to rabies virus. The stained impressions were viewed using fluorescence microscopy (Mayes and Rupprecht 2015). When labeled antibody was incubated with rabies suspect brain tissue, it would bind to rabies antigen (Hosseini and Asgary 2015).

\section{In vitro antirabies assay:}

The in vitro antirabies activity of the plant extracts were evaluated by FAT assay. Vero cell lines were trypsinized and $2 \times 10^{5}$ cells $/ \mathrm{ml}$ were seeded in a 96-well tissue culture micro plate and 
incubated at $37^{\circ} \mathrm{C}$ for $72 \mathrm{~h}$. After the incubation period, $50 \mu 1$ of rabies virus suspension were added to confluent cell monolayers in a 96-well plate and allowed to stand for $1 \mathrm{~h}$ to enable virus adsorption. Thereafter, different concentrations $(2 \mathrm{mg} / \mathrm{ml}, 4 \mathrm{mg} / \mathrm{ml}$ and $8 \mathrm{mg} / \mathrm{ml})$ of each extract based on cytotoxicity test result were added in triplicate into all the wells with the exception of the negative control wells that contained only Vero cells and the virus control that contained an equal virus concentration but lacked the plant extract. The plates were incubated at $37^{\circ} \mathrm{C}$ in $5 \% \mathrm{CO}_{2}$ humidified incubator for $72 \mathrm{~h}$. The medium was decanted and the cells were fixed by adding cold acetone $\left(50 \mu \mathrm{l}\right.$ per well) and kept at $4^{\circ} \mathrm{C}$ for 30 minutes. After discarding the acetone, cells were stained by direct polyclonal florescent-labeled antibody for 30 minutes and then washed ( 3 times) with 0.01 M PBS, air dried, and visualized under an inverted fluorescence microscope. Reading was qualitative, every well that shows specific fluorescence was considered to be positive.

\section{Results and Discussion}

\section{Phytochemical study result of extracts}

In the present study the result of qualitative phytochemical analysis of all extracts from the three plants using different standard methods showed positive results for alkaloids, but negative for saponins as shown in Table 1 below. The study also revealed the presence of terpenoids in all the extracts except the ethanol extract from leaf of Justicia schimperiana. From the three plants studied, only Croton macrostachyus showed flavonoids in its three extracts. The Libermann Burchard test failed to show the presence of steroids in the ethanolic extract, but gave a positive result with the methanolic and water extracts. 
Table 1: Different phytochemical components in the ethanol, methanol and water extracts of the leaves of Justicia schimperiana and Ricinus communis and the stem bark of Croton macrostachyus plants

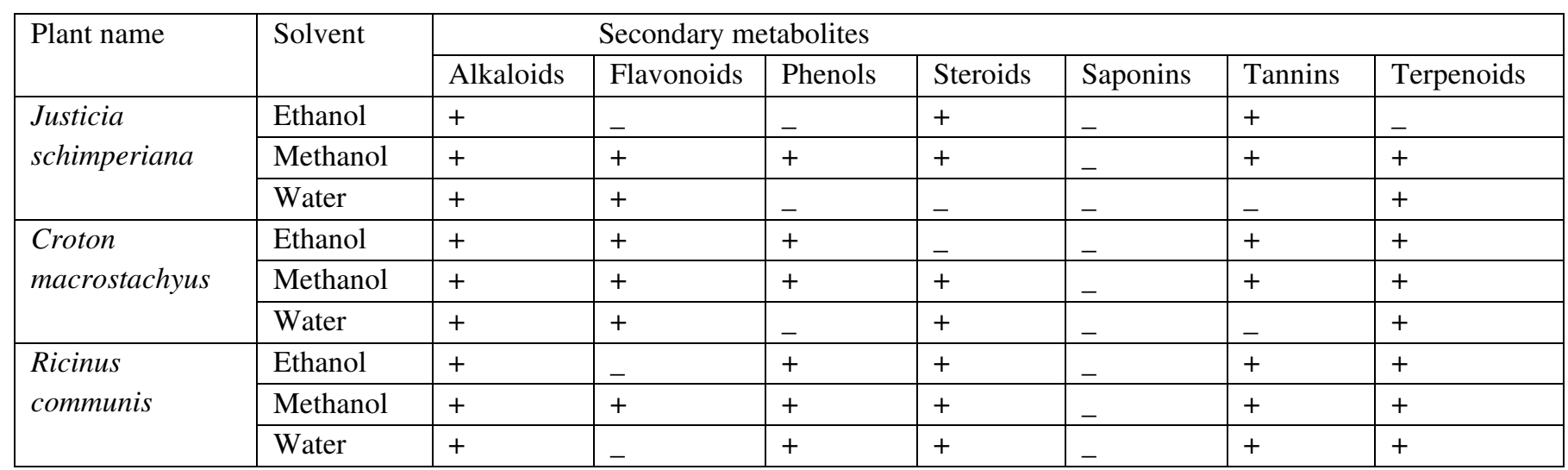

Where, $+=$ Presence and $\_=$Absence

\section{The result of acute oral toxicity test}

The acute toxicity results showed no evidence of toxicity of the ethanol, $80 \%$ methanol and water extracts of Justicia schimperiana (leaf), Croton macrostachyus (stem bark) and Ricinus communis (leaf) in mice administered at $1000 \mathrm{mg} / \mathrm{kg}, 2000 \mathrm{mg} / \mathrm{kg}$ and $3000 \mathrm{mg} / \mathrm{kg}$. No abnormalities were recorded at three doses with regard to food consumption, water intake and body weight of the mice. This shows that the plant extracts could be well tolerated up to the dose of $3000 \mathrm{mg} / \mathrm{kg}$ body weight of Swiss albino mice. However, at higher doses, i.e. $4000 \mathrm{mg} / \mathrm{kg}$ and $5000 \mathrm{mg} / \mathrm{kg}$, mice showed common signs of toxicity like low locomotion, weakness and erection of hairs including death in the course of acute study. As a result, the LD50 of the extracts could be greater than $3000 \mathrm{mg} / \mathrm{kg}$ body weight. It suggested that the extracts may not be completely safe at a dose higher than $3000 \mathrm{mg} / \mathrm{kg}$. According to the (Hodge and Sterner 1943) toxicity scale, the ethanol, methanol and aqueous extracts of Justicia schimperiana (leaf), Croton macrostachyus (stem bark) and Ricinus communis (leaf) were placed in category IV (500 mg/kg-5000 mg/kg, p.o.), and hence classified as slightly toxic.

The percentage of mice that died at each dose was transformed to probits using Finney's method. According to Finney's method the log dose at probit 5.0 (Log LD50) for the ethanol, methanol and water extracts of Justicia schimperiana were found to be 3.60, 3.54 and 3.65 and hence, LD50 was calculated by taking antilog of the Log LD50 values of each extract and found to be $4000 \mathrm{mg} / \mathrm{kg}$, 
$3500 \mathrm{mg} / \mathrm{kg}$ and $4500 \mathrm{mg} / \mathrm{kg}$ body weight respectively (Table 2). The acute toxicity study in LD50 determination showed that methanol leaf extract of Justicia schimperiana is more toxic than the ethanol and water leaf extracts of the plant.

Table 2: Mice treated with Justicia schimperiana extracts, and responses in acute toxicity testing

\begin{tabular}{|l|l|l|l|l|}
\hline Group & Dose $(\mathrm{mg} / \mathrm{kg})$ & Log Dose & Death n (\%) & Probits \\
\hline \multirow{4}{*}{ A1 } & $1000,2000,3000$ & $3,3.30,3.48$ & $0(0 \%)$ & 2.76 \\
\cline { 2 - 5 } & 4000 & 3.60 & $3(50 \%)$ & 5.00 \\
\cline { 2 - 5 } & 5000 & 3.70 & $5(83 \%)$ & 5.95 \\
\hline \multirow{4}{*}{ 1 } & $1000,2000,3000$ & $3,3.30,3.48$ & $0(0 \%)$ & 2.76 \\
\cline { 2 - 5 } & 4000 & 3.60 & $4(67 \%)$ & 5.44 \\
\cline { 2 - 5 } & 5000 & 3.70 & $6(100 \%)$ & 7.24 \\
\hline \multirow{3}{*}{ 1 } & $1000,2000,3000$ & $3,3.30,3.48$ & $0(0 \%)$ & 2.76 \\
\cline { 2 - 5 } & 4000 & 3.60 & $0(0 \%)$ & 2.76 \\
\cline { 2 - 5 } & 5000 & 3.70 & $4(67 \%)$ & 5.44 \\
\hline
\end{tabular}

Where, $\mathrm{A} 1=$ group of mice treated with ethanol extracts of Justicia schimperiana, B1 = mice treated with $80 \%$ methanol extracts of Justicia schimperiana and $\mathrm{C} 1=$ mice treated with water extracts of Justicia schimperiana. Similarly, the lethal dose (LD50) of the ethanol, methanol and water extracts of the leaves of Ricinus communis was also greater than $3000 \mathrm{mg} / \mathrm{kg}$ body weight of mice. The Log LD50 for the ethanol and water extracts of Ricinus communis was found to be 3.54 but, its methanolic extract was found to be 3.60 . Thus, the LD50 values were found to be $3500 \mathrm{mg} / \mathrm{kg}$ for the ethanol and water extracts and $4000 \mathrm{mg} / \mathrm{kg}$ for the methanol extract of the plant which were calculated by taking antilog of 3.54 and 3.60. Therefore, the ethanol and water leaf extract of Ricinus communisis more toxic than the methanol extract of the plant.

The lethal dose (LD50) of the ethanol, methanol and water extracts of the stem bark of Croton macrostachyus were also greater than $3000 \mathrm{mg} / \mathrm{kg}$ body weight of mice. The Log LD50 for the ethanol and methanol extracts of Croton macrostachyus was found to be 3.54. Thus, LD50 was calculated by taking antilog of 3.54 and found to be $3500 \mathrm{mg} / \mathrm{kg}$ body weight. Whereas, the Log LD50 for the water extract was found to be 3.59 hence, the LD50 value was $3900 \mathrm{mg} / \mathrm{kg}$.

\section{Cytotoxicity determination of plant extracts in Vero cell line}


Evaluation on Vero cell lines by using MTT assay showed that the 50\% cytotoxic concentration (CC50) values of the ethanol and aqueous extracts of three plants; Justicia schimperiana, Croton macrostachyus and Ricinus communis were found to be above $12.8 \mathrm{mg} / \mathrm{ml}$.

However, the $50 \%$ cytotoxic concentration (CC50) value of the methanol extracts from Justicia schimperiana and Croton macrostachyus were found to be $9.6 \mathrm{mg} / \mathrm{ml}$ and $8 \mathrm{mg} / \mathrm{ml}$ whereas, Ricinus communis showed above $12.8 \mathrm{mg} / \mathrm{ml}$ (Table 3).

Table 3: Effect of the methanol extracts of three plants on Vero cells

\begin{tabular}{|l|l|l|l|l|l|l|l|l|l|l|}
\hline & Concentration $(\mathrm{mg} / \mathrm{ml})$ & \multicolumn{3}{|l|}{ Absorbance 490nm } & \multicolumn{2}{l|}{ \% cell viability } & \multicolumn{2}{l|}{ \% cytotoxicity } \\
\cline { 3 - 11 } & & JS & CM & RC & JS & CM & RC & JS & CM & RC \\
\hline A & 12.8 & 0.21 & 0.22 & 0.24 & 46.7 & 49 & 53.3 & 53.3 & 51 & 46.7 \\
\hline B & 6.4 & 0.23 & 0.21 & 0.25 & 51 & 46.7 & 55.5 & 49 & 44.5 & 44.5 \\
\hline C & 3.2 & 0.24 & 0.23 & 0.28 & 53.3 & 51 & 62.2 & 46.7 & 49 & 37.8 \\
\hline D & 1.6 & 0.26 & 0.25 & 0.30 & 57.8 & 55.5 & 66.7 & 42.2 & 44.5 & 33.3 \\
\hline E & 0.8 & 0.31 & 0.28 & 0.31 & 68.9 & 62.2 & 68.9 & 31.1 & 37.8 & 31.1 \\
\hline F & 0.4 & 0.34 & 0.36 & 0.33 & 75.5 & 80 & 73.3 & 24.5 & 20 & 26.7 \\
\hline G & Control cells & 0.45 & 0.45 & 0.45 & 100 & 100 & 100 & 0 & 0 & 0 \\
\hline
\end{tabular}

$\mathrm{JS}=$ Justicia schimperiana; $\mathrm{CM}=$ Croton macrostachyus; $\mathrm{RC}=$ Ricinus communis

Generally, the percentage viability was found to be increasing with decreasing concentration of test extracts. The MTT assay results revealed that all extracts tested were non-cytotoxic and exhibited CC50 values above the cut-off point which is $30 \mu \mathrm{g} / \mathrm{ml}$. An extracts can be considered as non-cytotoxic if the CC50 is higher than $30 \mu \mathrm{g} / \mathrm{ml}$ (Nondo et al. 2015).

\section{In vivo antirabies potential of plant extracts}

Group of mice infected with rabies virus but not treated with any of plant extracts showed $0 \%$ survival rate and a mean survival period of 9.5 days. However, oral treatment of mice infected with rabies virus with ethanol, methanol and water extracts of the leaves of Justicia schimperiana and Ricinus communis as well as the stem bark of Croton macrostachyus at a dose of $3000 \mathrm{mg} / \mathrm{kg}$ significantly $(\mathrm{p}<0.05)$ increased the mean survival time compared to those of negative control group (Table 4). Relatively higher mean survival time (22.16 days) was obtained when methanol extract of Ricinus communis was administered to mice at a dose of $3000 \mathrm{mg} / \mathrm{kg}$. One mouse from the negative control group died within four days of inoculation with PV but, didn't show any antigen against rabies virus which indicate the death was due to accidental rather than the effect of the virus. Death from samples taken from those at moribund state was due to the action of rabies 
virus PV strain because all the samples showed a viral antigen but, most of the samples from survivors indicate negative for antigen detection.

Table 4: Antirabies effect of plant extracts on mice survival time $(\mathrm{n}=6)$ at $3000 \mathrm{mg} / \mathrm{kg}$

\begin{tabular}{|c|c|c|c|c|c|c|}
\hline \multirow[t]{2}{*}{ Group } & \multirow[t]{2}{*}{ Treatment } & \multirow{2}{*}{$\begin{array}{l}\text { Route of } \\
\text { administration }\end{array}$} & \multirow{2}{*}{$\begin{array}{l}\text { Survival } \\
\text { time/days } \\
(\text { mean } \pm \text { SD })\end{array}$} & \multicolumn{3}{|l|}{ FAT results } \\
\hline & & & & $\begin{array}{l}\text { Death within } \\
\text { four days }\end{array}$ & $\begin{array}{l}\text { Moribund } \\
\text { mice }\end{array}$ & $\begin{array}{l}\text { Survivors/sac } \\
\text { rificed mice }\end{array}$ \\
\hline $\mathrm{I}$ & Distilled water & Os & $24 \pm 2.529$ & ND & NM & - \\
\hline II & $\mathrm{PV}$ & IC & $9.5 \pm 0.438$ & - & + & NS \\
\hline IIIA & $J S$ ethanol extract & IC, Os & $13.8 \pm 0.327$ & ND & + & + \\
\hline IVA & $J S$ methanol extract & $\mathrm{IC}, \mathrm{Os}$ & $14.3 \pm 0.413$ & ND & + & $\ldots$ \\
\hline VA & $J S$ water extract & IC, Os & $13.3 \pm 0.413$ & ND & + & - \\
\hline IIIB & $C M$ ethanol extract & $\mathrm{IC}, \mathrm{Os}$ & $18 \pm 1.132$ & ND & + & + \\
\hline IVB & $C M$ methanol extract & $\mathrm{IC}, \mathrm{Os}$ & $21.3 \pm 0.413$ & ND & + & _ \\
\hline VB & $C M$ water extract & $\mathrm{IC}, \mathrm{Os}$ & $21 \pm 1.78$ & ND & + & _- \\
\hline IIIC & $R C$ ethanol extract & IC, Os & $17.5 \pm 1.497$ & ND & + & - \\
\hline IVC & $R C$ methanol extract & $\mathrm{IC}, \mathrm{Os}$ & $22.16 \pm 2.287$ & ND & + & _ \\
\hline $\mathrm{VC}$ & $R C$ water extract & $\mathrm{IC}, \mathrm{Os}$ & $20.16 \pm 1.468$ & ND & + & _- \\
\hline
\end{tabular}

Where, I= Placebo administrated $1 \mathrm{ml}$ of dH2O; II=Negative control; JS=Justicia schimperiana; $\mathrm{CM}=$ Croton macrostachyus; $\mathrm{RC}=$ Ricinus communis; $\mathrm{IC}=$ Intracerebral; Os= Oral; ND= No death; $\mathrm{NM}=$ No moribund mice; NS= No survivor; $-=$ No antigen detected and $+=$ Antigen detected

\section{In vitro antirabies effect of plant extracts:}

The in vitro antirabies activity of medicinal plant extracts (Justicia schimperiana, Croton macrostachyus and Ricinus communis) were evaluated by fluorescent antibody assay and the CC50 value, IC50 value and the selective index (SI) were calculated (Table 5). Methanol extracts from all plant samples at a concentration of $8 \mathrm{mg} / \mathrm{ml}$ showed a $100 \% \mathrm{RV}-\mathrm{PV}$ inhibition. The half maximal inhibitory concentration (IC50) values were ranged from $3 \mathrm{mg} / \mathrm{ml}$ to $6 \mathrm{mg} / \mathrm{ml}$ with the selectivity indices (SI) of each tested material above 2.13. The water extracts of all tested samples and the ethanol extract of Justicia schimperiana showed relatively the highest IC50 values. The results exhibit that smaller the IC50 value higher the antirabies activity. Ethanol extracts of Croton macrostachyus stem bark and Ricinus communis leaf as well as methanol extract of Ricinus communis shows highest SI value against RV-PV with the value of $>4.27$. The selectivity indices (SI = CC50/IC50) of Ricinus communis (leaf) methanol extract (SI>4.27) was found to be higher than the methanol extracts of Justicia schimperiana (SI=3.2) and Croton macrostachyus (SI=2.7). SI values less than one considered as weak, greater than one moderate, and greater than three considered as good antiviral activities (Bagla et al. 2012). The IC50 value and the selective index 
(SI) of ethanol, methanol and aqueous extracts of Justicia schimperiana (leaf) were calculated and found to be $6 \mathrm{mg} / \mathrm{ml} \quad(\mathrm{SI}>2.13), 3 \mathrm{mg} / \mathrm{ml} \quad(\mathrm{SI}=3.2)$, and $6 \mathrm{mg} / \mathrm{ml} \quad(\mathrm{SI}>2.13)$ respectively. The methanol extract exhibited smaller IC50 value when compared to the other extracts. Croton macrostachyus stem bark showed 50\% inhibition of RV-PV at 3mg/ml (ethanol and methanol extracts) and $6 \mathrm{mg} / \mathrm{ml}$ (aqueous extracts). The ethanol extract of Croton macrostachyus stem bark contain antirabies active compounds with good activity (SI>4.27) whereas, the methanol (SI=2.7) and aqueous ( $\mathrm{SI}>2.13$ ) extracts had shown a moderate antirabies activity against PV strain. The IC50 values of ethanol, methanol and aqueous extracts of Ricinus communis (leaf) was found to be $3 \mathrm{mg} / \mathrm{ml}(\mathrm{SI}>4.27), 3 \mathrm{mg} / \mathrm{ml}(\mathrm{SI}>4.27)$ and $6 \mathrm{mg} / \mathrm{ml}(\mathrm{SI}>2.13)$ respectively. This indicates that methanol and ethanol extracts had a good antirabies activity against PV strain while, aqueous extract with moderate activity.

Table 5: Cytotoxicity (CC50), inhibition concentration (IC50) and selectivity index (SI) of plant extracts

\begin{tabular}{|l|l|l|l|l|}
\hline Plant name & Solvent & $\mathrm{CC}_{50}$ & $\mathrm{IC}_{50}$ & SI \\
\hline \multirow{5}{*}{ Justicia schimperiana } & Ethanol & $>12.8 \mathrm{mg} / \mathrm{ml}$ & $6 \mathrm{mg} / \mathrm{ml}$ & $>2.13$ \\
\cline { 2 - 5 } & Methanol & $9.6 \mathrm{mg} / \mathrm{ml}$ & $3 \mathrm{mg} / \mathrm{ml}$ & 3.2 \\
\cline { 2 - 5 } & Aqueous & $>12.8 \mathrm{mg} / \mathrm{ml}$ & $6 \mathrm{mg} / \mathrm{ml}$ & $>2.13$ \\
\hline Croton macrostachyus & Ethanol & $>12.8 \mathrm{mg} / \mathrm{ml}$ & $3 \mathrm{mg} / \mathrm{ml}$ & $>4.27$ \\
\cline { 2 - 5 } & Methanol & $8 \mathrm{mg} / \mathrm{ml}$ & $3 \mathrm{mg} / \mathrm{ml}$ & 2.7 \\
\cline { 2 - 5 } & Aqueous & $>12.8 \mathrm{mg} / \mathrm{ml}$ & $6 \mathrm{mg} / \mathrm{ml}$ & $>2.13$ \\
\hline Ricinus communis & Ethanol & $>12.8 \mathrm{mg} / \mathrm{ml}$ & $3 \mathrm{mg} / \mathrm{ml}$ & $>4.27$ \\
\cline { 2 - 5 } & Methanol & $>12.8 \mathrm{mg} / \mathrm{ml}$ & $3 \mathrm{mg} / \mathrm{ml}$ & $>4.27$ \\
\cline { 2 - 5 } & Aqueous & $>12.8 \mathrm{mg} / \mathrm{ml}$ & $6 \mathrm{mg} / \mathrm{ml}$ & $>2.13$ \\
\hline
\end{tabular}

SI: Selectivity index, CC50 value was divided by the IC50 value

\section{Conclusions}

The phytochemical analysis showed that the ethanol, methanol and water extracts of the leaves of Justicia schimperiana and Ricinus communis as well as the stem bark Croton macrostachyus contains a mixture of phytochemicals as alkaloids, flavonoids, phenols, steroids, tannins and terpenoids but lack saponins. All the extracts were slightly toxic in animal model but non cytotoxic in Vero cell lines. All the Plant extracts had a moderate to good antirabies activity against PV strain. The methanol plant extracts gave more antirabies activity compared to ethanol and water extracts in mice model. 


$\begin{array}{ll}\text { List of abbreviations } \\ \text { BHK } & \text { Baby hamster kidney } \\ \text { CC50 } & \text { Cytotoxicity Concentration 50\% } \\ \text { CM } & \text { Croton macrostachyus } \\ \text { IC50 } & \text { Inhibitory Concentration 50\% } \\ \text { JS } & \text { Justicia schimperiana } \\ \text { LD50 } & \text { Medium Lethal Dose } \\ \text { MTT } & \text { 3-(4,5-dimethylthiazol-2-yl)-2,5-diphenyltetrazolium bromide } \\ \text { PEP } & \text { Post-Exposure Prophylaxis } \\ \text { PrEP } & \text { Pre-Exposure Prophylaxis } \\ \text { PV } & \text { Pasteur Virus } \\ \text { RC } & \text { Ricinus communis }\end{array}$

\section{List of Tables}

Table 1: Different phytochemical components in the ethanol, methanol and water extracts of the leaves of Justicia schimperiana and Ricinus communis and the stem bark of Croton macrostachyus plants

Table 2: Mice treated with Justicia schimperiana extracts, and responses in acute toxicity testing Table 3: Effect of the methanol extracts of three plants on Vero cells

Table 4: Antirabies effect of plant extracts on mice survival time $(\mathrm{n}=6)$ at $3000 \mathrm{mg} / \mathrm{kg}$ Table 5: Cytotoxicity (CC50), inhibition concentration (IC50) and selectivity index (SI) of plant extracts

\section{List of figure}

Figure 1: Ethical approval sheet 


\section{Declarations}

\section{Funding}

The authors received no financial support for the research, authorship, and/or publication of this article.

\section{Conflicts of interest/Competing interests}

Authors declare that they need no any competing interests.

\section{Availability of data and material}

All data generated or analyzed during this study are included in this manuscript. Data presented are mainly results obtained from the study and has not been submitted or published elsewhere for publication. The datasets (Plant samples) supporting the conclusions of this article are available in the National Herbarium, Department of Plant Biology and Biodiversity management, Addis Ababa University, Ethiopia, where voucher specimens were deposited (Justicia schimperiana 001; Croton macrostachyus 002 and Ricinus communis 003).

\section{Code availability}

Voucher specimens are deposited as 001, 002 and 003 for Justicia schimperiana, Croton macrostachyus and Ricinus communis.

\section{Authors' contributions}

All authors contributed to and approved the manuscript. Yeweynshet Tesera and Asnake Desalegn conceived and planned the presented experiments. Birhanu Hurisa and Anberbir Alemu contributed to sample preparation. Jemal Mohammed and Sileshi Degu carried out the experiments. Yeweynshet Tesera wrote the manuscript with support from Ashenif Tadele, Ayele Bizuneh and Abebe Mengesha. Demise Mulugeta and Sintayehu Ashenafi contributed to the analysis and/or interpretation of the results. All authors provided critical feedback and revising the manuscript critically for important intellectual content. 


\section{Ethics approval}

Ethical approval for the study was sought from the college of Natural \& Computational Science Institutional Review Board (CNS IRB), Addis Ababa University, Ethiopia. The animals were handled according to the international guidelines for the care and use of laboratory animals. For the care and use of animals, the ARRIVE guidelines (Animal Research: Reporting of in Vivo Experiments) were followed (Percie et al. 2020).

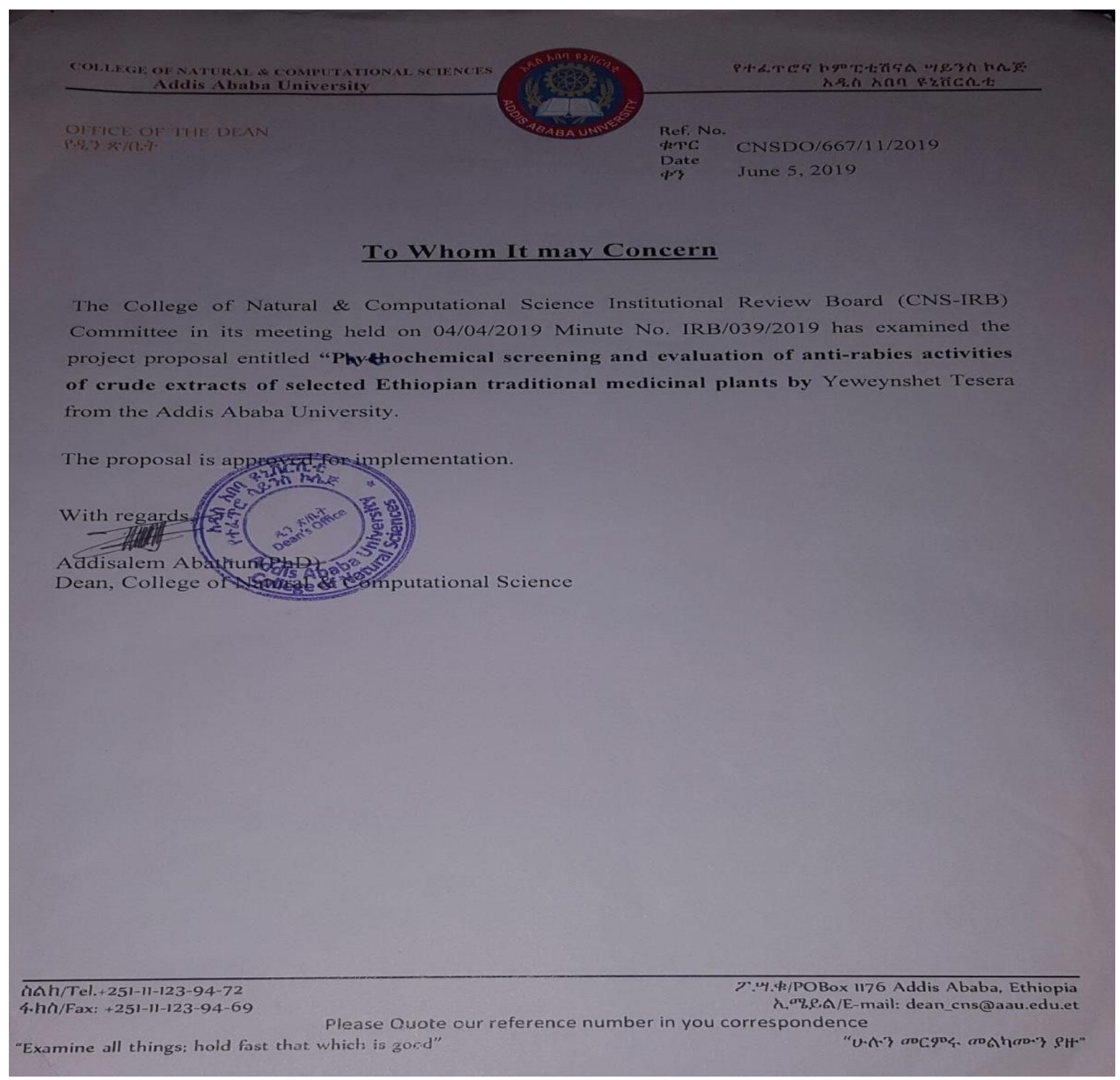

Figure 1: Ethical approval sheet 


\section{Consent to participate}

Not applicable

\section{Consent for publication}

Not applicable

\section{Acknowledgements}

We would like to acknowledge Mr. Eyob Debebe and Mr. Asfaw Meresa for their sincere technical

supports. We would also acknowledge Ethiopian Public Health Institute and Addis Ababa University for helping us to successfully complete our Master of Science degree (MSc) in applied microbiology. 


\section{References}

1. Ammerman NC, Beier-Sexton M, Azad AF (2008) Growth and Maintenance of Vero Cell Lines. Curr Protoc Microbiol 1:1-10. https://doi.org/10.1002/9780471729259.mca04es11

2. Asefa Deressa, Kedir Hussen, Dawit Abebe, Demekech Gera (2010) Evaluation of the Efficacy of Crude Extracts of Salix subserrata and Silene macroselen for the treatment of rabies in Ethiopia. Ethiop Vet J 14(2):1-16.

3. Asfaw Meresa, Sileshi Degu, Ashenif Tadele, Bekesho Geleta, Hiwot Moges, Firehiwot Teka, Netsanet Fekadu (2017) Medicinal Plants Used for the Management of Rabies in Ethiopia - A Review. Med Chem (Los Angeles) 7(2):795-806.

4. Balcha Chernet, Abdela Nejash (2016). Review of rabies preventions and control. Int J Life Sciences 4(2):293-301.

5. Banu KS, Cathrine L (2015) General Techniques Involved in Phytochemical Analysis. IJARCS 2(4):25-32.

6. Birhanu Hurisa, Abebe Mengesha, Bethlehem Newayesilassie, Sisay Kerga, Gezahegn Kebede, Bankovisky D, Metlin A, Kelbessa Urga (2013) Production of Cell Culture Based Anti-rabies Vaccine in Ethiopia. Procedia in Vaccinology 7:2-7.

7. Blanton JD, Palmer D, Rupprecht CE (2010). Rabies surveillance in the United States during 2009. Journal of the American Veterinary Medical Association, 237(6), 646-657. doi:10.2460/javma.237.6.646

8. Crowcroft NS, Thampi N (2016) The prevention and management of rabies. BMJ 350(7827):1-9.

9. Dean DJ, MK Abelseth (1973) The fluorescent antibody test. 73-83.

10. Fayyad AGS, Ibrahim N, Yaakob WA (2014) Phytochemical screening and antiviral activity of Marrubium vulgare. Mal J Microbiol 10(2):106-111.

11. Hemachudha T, Ugolini G, Wacharapluesadee S, Sungkarat W, Shuangshoti S, Laothamatas J (2013). Human rabies: neuropathogenesis, diagnosis, and management. The Lancet Neurology 12(5), 498-513. doi:10.1016/s1474-4422(13)70038-3

12. Hodge HC, Sterner JH (1943) Determination of substance acute toxicity by LD50. Am. Ind.Hyg. Assoc.10:93-96.

13. Hosseini P, Asgary V (2015) Postmortem Diagnosis of Rabies in Animal Brain by Fluorescent Antibody Testing. Intl. Conf. on AABES.146-147. 
14. Hussain I, Ullah R, Ullah R, Khurram M., Ullah N, Baseer N, Khan F., Khattak M, Zahoor M, KhanJ, Khan N (2011) Phytochemical analysis of selected medicinal plants. Afr J Biotech 10(38):7487-7492.

15. I.O. Okonko, O.B. Adedeji, E.T. Babalola, E.A. Fajobi, A. Fowotade and O.G. Adewale (2010) Why Is There Still Rabies in the World? - An Emerging Microbial and Global Health Threat. Global Veterinaria, 4 (1): 34-50 http://www.idosi.org/gv/gv4(1)10/5.pdf

16. Jemal Abdela, Ephrem Engidawork, Workneh Shibeshi (2014) In vivo antimalarial activity of solvent fractions of the leaf of Justicia schimperiana Hoechst. Ex Nees (Acanthaceae) against Plasmodium berghei in mice. Ethiop Pharm J 30:95-108.

17. Kaare M, Lembo T, Hampson K, Ernest E, Estes A, Mentzel C, Cleaveland S (2009) Rabies control in rural Africa: Evaluating strategies for effective domestic dog vaccination. Vaccine, 27(1):152-160.

18. Khalid S, Shahzad A, Basharat N, Abubakar M, Anwar P (2018) Phytochemical Screening and Analysis of Selected Medicinal Plants in Gujrat. J. Phytochemistry Biochem 2(1):2-4.

19. Knobel DL, Cleaveland S, Coleman PG, Fèvre EM, Meltzer MI, Miranda ME, Shaw A, Zinsstag J, Meslin FX (2005) Re-evaluating the burden of rabies in Africa and Asia. Bull World Health Organ. 2005 May;83(5):360-8. PMID: 15976877; PMCID: PMC2626230.

20. Kuzmin IV, Rupprecht CE (2008). Rabies Virus. Encyclopedia of Virology, 367-373. doi:10.1016/b978-012374410-4.00482-9

21. Leung AK, Davies HD, Hon KL (2007) Rabies: epidemiology, pathogenesis, and prophylaxis. Adv Ther. Nov-Dec;24(6):1340-7. doi: 10.1007/BF02877781. PMID: 18165217.

22. Mayes B, Rupprecht CE (2015) Direct Fluorescent Antibody Test for Rabies Diagnosis. Current Laboratory Techniques in Rabies Diagnosis, Res and Prev. 2:83-92.

23. Nafiu MO, Abdulsalam TA, Akanji MA (2013) Phytochemical Analysis and Antimalarial Activity Aqueous Extract of Lecaniodiscus cupanioides Root J Trop Med 14(2013):1-4.

24. Nie J, Wu X, Ma J, Cao S, Huang W, Liu QLi X, Li Y, Wang Y (2017) Rabies virus neutralization assays based on a high-titer pseudovirus system. Scientific Reports 7(1): 112.

25. Nondo RSO, Moshi MJ, Erasto P, Zofou D, Njouendou AJ, Wanji S, Ngemenya MN, Kidukuli AW, Masimba PJ, Titanji, VPK (2015) Evaluation of the cytotoxic activity of 
extracts from medicinal plants used for the treatment of malaria in Kagera and Lindi regions, Tanzania. J App Pharm Sci 5(04):007-012.

26. OECD (2001) OECD Guidelines for the Testing of Chemicals. Acute Oral Toxicity - Fixed Dose Procedure.1-14.

27. Percie SN, Hurst, V, Ahluwalia A, Alam S, Avey MT, Baker M, Würbel H (2020). The ARRIVE guidelines 2.0: Updated guidelines for reporting animal research. PLOS Biology, 18(7), e3000410. doi: 10.1371/journal.pbio.3000410.

28. Petros Admasu, Asefa Deressa, Abebe Mengistu, Gashaw Gebrewold, Teka Feyera (2014) In vivo antirabies activity evaluation of hydroethanolic extract of roots and leaves of Phytolacca dodecandra. Global Veterinaria 12(1):12-18.

29. Ramakrishnan MA (2016) Determination of 50\% endpoint titer using a simple formula. World J Virol 5(2):85-86.

30. Sasidharan S, Chen Y, Saravanan D, Sundram KM, Latha LY (2011) Extraction, isolation and characterization of bioactive compounds from plants' extracts. Afr J Tradit Compl Altern Med 8(1):1-10.

31. Singh R, Singh KP, Cherian S, Saminathan M, Kapoor S, Manjunatha Reddy GB, Dhama K (2017). Rabies -epidemiology, pathogenesis, public health concerns and advances in diagnosis and control: a comprehensive review. Veterinary Quarterly 37(1), 212-251. doi:10.1080/01652176.2017.1343516

32. Soltanian S, Sheikhbahaei M, Mohamadi N (2017) Cytotoxicity Evaluation of Methanol Extracts of Some Medicinal Plants on P19 Embryonal Carcinoma Cells. Applied Pharmaceutical Science 7(07):142-149.

33. Vural SA, Bozkurt MF, Ozkara A, Alcigir ME, Ilhan FS (2016). Apoptosis in natural rabies virus infection in dogs. J Vet Res 60(3): 227-231.doi:10.1515/jvetres-2016-0034

34. Wadood A, Ghufran M, Jamal SB, Naeem M, Khan A, Ghaffar R, Asnad (2013) Phytochemical Analysis of Medicinal Plants Occurring in Local Area of Mardan. Biochem Anal Biochem 2(4):2-5.

35. Webster LT, Clow AD (1937) Propagation of rabies virus in tissue culture. J. Exp Med 66(1):125-131.

36. Zohra SF, Meriem B, Samira S, Muneer A (2012) Phytochemical Screening and identification of some compounds from Mallow. J Nat Prod Plant Resour 2(4):512-516. 
37. Zulu GC, Sabeta CT, \& Nel LH (2009). Molecular epidemiology of rabies: Focus on domestic dogs (Canis familiaris) and black-backed jackals (Canis mesomelas) from northern South Africa. Virus Research, 140(1-2), 71-78. doi: 10.1016/j.virusres.2008.11.004 


\section{Figures}

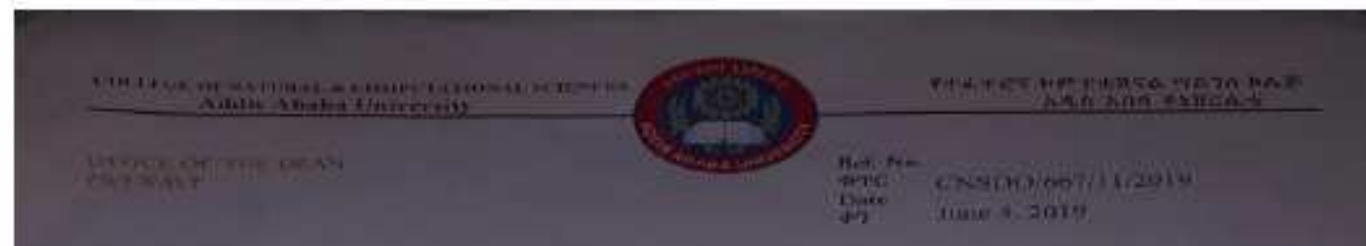

\section{To Whom tt maxcionecrn}

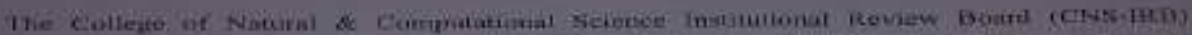

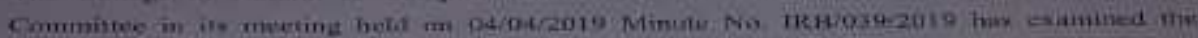

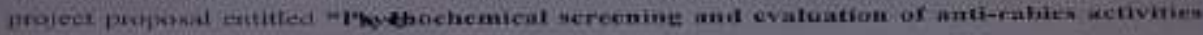

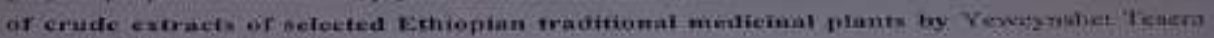

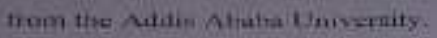

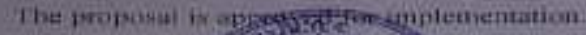
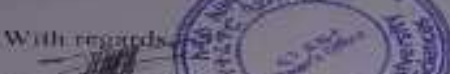

(1)

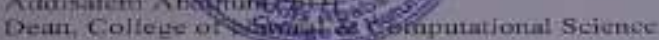

\section{Figure 1}

Ethical approval sheet 